\title{
The Role of VEGF in the Process of Neovasculogenesis
}

\author{
Aleksandra Sobczyńska-Rak \\ Department of Veterinary Surgery, Faculty of Veterinary Medicine, \\ Lublin University of Life Sciences, Lublin, \\ Poland
}

\section{Introduction}

Neovasculogenesis is a multi-stage process of blood vessel formation which plays a vital role in neoplasia. The formation of blood vessels in tumours is closely related to invasive cancerous growth.

The process of angiogenesis is closely regulated by the system of cooperating stimulants and inhibitors. Factors stimulating neovasculogenesis are characterised by a fairly broad spectrum of activity. Three key attributes of proangiogenic factors have been identified as:

1. The specific effect on endothelial cells, i.e. the given factor's presence induces angiogenesis.

2. The presence of specific receptors in endothelial cells.

3. Neutralisation of the factor inhibits angiogenesis (Grunstein et al., 1999; McMahon, 2000; Szala \& Radzikowski, 1997).

There are a number of proteins that have been referred to as pro-angiogenic factors that actively participate in the formation of capillaries. VEGF meets all key requirements of being classified as a pro-angiogenic factor: it specifically affects vascular epithelial cells, it is present only during angiogenesis, it does not occur in adults unless new vessels are being formed. Its overexpression is connected to the formation of capillaries and its neutralisation inhibits the process (Grunstein et al., 1999; McMahon, 2000).

\section{VEGF - Vascular Endothelial Growth Factor}

The two main biological activities of VEGF - mitogenic activity and vascular permeability inducing activity - were described, purified and designated independently as VPF (vascular permeability factor) and VEGF (vascular endothelial growth factor).

The release of a vascular permeability-increasing agent by guinea pig hepatocarcinoma cells was reported in 1979 (Dvorak et al., 1979). Vascular leakage was subsequently used to monitor purification of VEGF from the supernatant of this (Senger et al., 1983; Senger et al., 1986) and of the human histiocytic lymphoma cell line U-937 (Connolly et al., 1989b). Therefore, the factor was later designated as vascular permeability factor -VPF ( Senger et al., 1983) or vasculotropin (Plouët et al., 1989). 
The mitogenic activity of this agent towards vascular endothelial cells was used to monitor its purification, and on the basis of its target cell selectivity the purified agent was designated VEGF (Ferrara \& Henzel, 1989; Gospodarowicz et al., 1989).

VEGF is a strong and specific mitogen for endothelial vascular cells of the circulatory and lymphatic systems (Baillie et al., 2001; Barańska et al., 2005; Chhieng et al., 2003). It is secreted by a number of cell types: $T$ lymphocytes, monocytes, macrophages, activated platelets, fibroblasts, smooth muscle cells, and most importantly neoplastic cells (Namiecińska et al., 2005; Restucci et al., 2002; Rosen, 2002; Szala \& Radzikowski, 1997). The factor is characterised by mitogenic activity towards endothelial cells, which causes their increased proliferation, migration and formation of new vessels from endothelial cells (Baillie et al., 2001; Bałan, 2000; Breier \& Risau, 1996; Conti, 2002; Dvorak, 2002; Epstein et al., 2001; Gawrychowski et al., 1997; Nicosia, 1998; Restucci et al., 2002; Rofstad \& Halsor, 2000; Terman \& Stoletov, 2001). The newly formed blood vessels serve not only to provide neoplastic cells with nutrients and oxygen, but are also responsible for the neoplastic cells permeating to the circulatory system, thus facilitating tumour dissemination and metastasis (Litwiniuk et al., 2007).

VEGF is also a 50 times stronger inductor of blood vessel permeability than histamine, it allows the permeation of plasma proteins as well as neoplastic cells into the extravascular space, allowing for their hyperplasia into the new location (Epstein et al, 2001; Kondo et al., 2000; Łojko \& Komarnicki, 2004; Szala \& Radzikowski, 1997).

VEGF is the main proangiogenic factor responsible for the formation of blood vessels in neoplastic tumours (Fang et al., 2001; Papetti \& Herman, 2002).

It was demonstrated that the increase of VEGF-A expression is one of the mechanisms greatly enhances a tumour's resistance to chemotherapy (Volk et al., 2008). VEGF-A protects tumor cells from apoptosis through autocrine activation of VEGF-A receptors expressed on tumour cells ( Volk et al., 2011).

\subsection{VEGF-A isoforms}

VEGF is a glycosilated homodimer whose molecular mass is 46-48 kDa (Barańska et al., 2005, Chhieng et al., 2003; Clifford et al., 2001; Kondo et al., 2000; Nicosia, 1998; Papetti \& Herman, 2002; Ranieri et al., 2004). The gene for VEGF-A is located on chromosone 6 at band 21.3, and comprises 8 exons separated by 7 introns (Ferrara, 1999; Gruchlik et al., 2007). Through alternative mRNA maturation, isoforms of VEGF are formed comprising respectively 121, 145, 148, 162, 165, 183, 189, or 206 amino acids $\left(\mathrm{VEGF}_{121}, \mathrm{VEGF}_{145}, \mathrm{VEGF}_{148}\right.$, $\mathrm{VEGF}_{183}, \mathrm{VEGF}_{165}, \mathrm{VEGF}_{189}, \mathrm{VEGF}_{206}$ ). The shortest isoform, $\mathrm{VEGF}_{121}$, is encoded by exons 1-5 and 8, VEGF165 includes additionally exon 7. $\mathrm{VEGF}_{189}$ and $\mathrm{VEGF}_{206}$ mRNAs contain all 8 exons, and the usage of a variable 5'-splice donor site within exon 6 creates the difference between the VEGF189 and $\mathrm{VEGF}_{206}$ mRNA .The particular isoforms vary in terms of biochemical and biological qualities (Bałan, 2000; Barańska et al., 2005; Ferrara, 1999; Ferrara \& Davis-Smyth 1997; Łojko \& Komarnicki, 2004; Łukasik et al., 2003; Namiecińska et al., 2005; Nicosia, 1998; Oshika et al., 1998; Papetti \& Herman, 2002; Webb et al., 1998; Yu et al., 2002). Additionally, a form of VEGF $_{110}$ also exists as a product of VEGF 165 and VEGF 189 proteolysis.

The most common form, synthesised by a wide range of both healthy and altered cells, which is at the same time the most active biologically, is VEGF 165 and VEGF VI21 $_{12}$ (Gruchlik et al., 2007). Other commonly observed isoforms are $\mathrm{VEGF}_{121}, \mathrm{VEGF}_{165}$, VEGF $\mathrm{V}_{189}$, while 
$\mathrm{VEGF}_{145}, \mathrm{VEGF}_{183}$ and $\mathrm{VEGF}_{206}$ are rarely observed in vivo, e.g. the longest of the forms is found exclusively in embryonic tissues (Barańska et al., 2005). VEGF 121 and VEGF $_{165}$ are soluble proteins observed extracellularly. $\mathrm{VEGF}_{121}$ is a weak acidic polypeptide that does not bind to heparin due to the lack of the heparin-binding domain encoded by exons 6 and 7. In contrast, $\mathrm{VEGF}_{165}$ is basic and binds to heparin. $\mathrm{VEGF}_{189}$ and $\mathrm{VEGF}_{206}$ are even more basic and bind to heparin with greater affinity. The differences in affinity for heparin affect the fate of the VEGF isoforms (Houck et al., 1992). VEGF 121 is secreted and is freely diffusible in the medium of transfected cells. VEGF 165 is also secreted but a significant fraction remains bound to heparin-containing proteoglycans. A part of $\mathrm{VEGF}_{165}$ remains anchored to the cell membrane and the extracellular matrix. $\mathrm{VEGF}_{189}$ and $\mathrm{VEGF}_{206}$ are alkaline and are found almost exclusively as proteins anchored to the extracellular matrix. They display stronger mitogenic activity than the shorter isoforms (Barańska et al., 2005; Gruchlik et al., 2007; Łojko \& Komarnicki, 2004; Łukasik et al., 2003). They may take the soluble form after binding with heparin as well as under the effect of heparinase, metaloproteases or other extracellular proteases. The mRNA molecule for all the isoforms comprises exons 1-5 carrying information necessary to recognise the specific receptors - VEGFR-1 or VEGFR-2. Discrepancies in this respect are observed only in terms of presence or absence of exons 6, 6', 7 or 8 . ( Michalski et al., 2003)

\subsection{The VEGF protein family}

Purified VEGF (VEGF-A) was first obtained by Gospodarowicz et al. and Ferrara and Hanzel in 1989 (Ferrara \& Henzel, 1989; Gospodarowicz et al., 1989). It is one of the most thoroughly studied factors partaking in all stages of angiogenesis.

In normal tissues, the highest levels of VEGF-A mRNA are found in adult lung, kidney, heart, and adrenal gland. Lower, but still readily detectable, quantities of VEGF-A transcript levels occur in liver, spleen, and gastric mucosa (Hoeban et al., 2004)

VEGF-A displays a variety of qualities, one of the most important of which is the increase of vascular permeability. The same allows blood proteins, e.g. plasminogen, fibrinogen, macrophages and platelets to permeate into the extravascular space.

Plasmitogen is transformed into plasmin which, through proteolytic action, activates metalloproteases destroying the basement membranes of the existing vessels. Fibrinogen is transformed into fibrin which provides a form of scaffold for the precipitating endothelial cells. Macrophages and platelets in turn stimulate angiogenesis by secreting cytokines and VEGF.

VEGF-A is the key mitogenic factor but it also displays strong protective action. It was observed that it can induce the expression of proteins which prevent apoptosis in blood vascular endothelial cells and increase the probability of the cells' survival ( Hoeban et al., 2004; Bałan \& Słowiński, 2008)

It was demonstrated that overexpression VEGF may inhibit differentiation and maturation of dendritic cells and thus weaken the host immunological response against a tumour (Swidzińska et al., 2006).

Furthermore, VEGF stimulates the expression of the tissue factor (TF) in ECs and monocytes, which facilitates the activation of blood coagulation (Wojtkiewicz \& Sierko, 2009).

At a molecular level, VEGF-A reprograms endothelial cell gene expression, leading to increased expression of a number of different proteins, including the procoagulant tissue 
factor, proteins associated with the fibrinolytic pathway, matrix metalloproteases, the GLUT-1 glucose transporter, nitric oxide synthase, numerous mitogens, and a number of antiapoptotic factors (e.g. bcl-2, A1, survivin, XIAP)( Bałan \& Słotwiński 2008).

VEGF-A is a cytokine which plays a key role in postnatal angiogenesis, both pathological, i.e. the formation of undesirable vessels (in tumours, retinopathy), and physiological (healing).

VEGF-A is over expressed not only by invasive cancer cells, but also by at least some premalignant lesions (eg, precursor lesions of breast, cervix, and colon cancers);furthermore, expression levels increased in parallel with malignant progression (Bałan \& Słotwiński 2008).

The VEGF group also includes other structurally related, yet varying in terms of biological activity, proteins VEGF-B, VEGF-C, VEGF-D and VEGF-E as well as the placental growth factor (PIGF) (Barańska et al., 2005; Łojko \& Komarnicki, 2004; Namiecińska et al., 2005; Papetti \& Herman, 2002; Ranieri et al., 2004; Terman \& Stoletov, 2001).

Cytokine VEGF-B was discovered in 1996 ( Grimmond et al., 1996; Olofsson et al., 1996). Its gene is located in the region of the 11q13 chromosome and contains 7 exons.

It is observed in two forms formed through alternative splicing of mRNA contained in molecule 167 or 186 of amino acids. VEGF-B is a VEGFR-1 ligand, and after the formation of the heterodimer from VEGF-A it can also react with the VEGF-2 receptor (Olofsson et al., 1998) The two splice isoforms, VEGF- $B_{167}$ and VEGF- $B_{186}$, differ in their C-terminal amino acid sequences and show different diffusion properties and receptor-binding affinities. Both isoforms are expressed in adult tissues, with the highest expression in the myocardium, brown adipose tissue (BAT), skeletal muscle and pancreas. The expression of VEGF-B is not induced by hypoxia, in contrast to all the other VEGF-ligands (Li et al., 2001)

VEGF - $B_{167}$ has a heparyn-binding domain so that upon secretion, VEGF - $\mathrm{B}_{167}$ binds to cellsurface heparyn sulphate proteoglycans. VRGF- $\mathrm{B}_{186}$ does not contain the heparin-binding domain and there-fore is more soluble ( $\mathrm{Li}, 2010)$

Several studies have shown that VEGF-B gene or protein transfer into different types of organs did not induce angiogenesis under most conditions (Li et al., 2009)

VEGF-B is not necessary in the process of angiogenesis, however, recent studies have shown that the factor is needed for vessel survival. In fact many researchers have suggested changing the VEGF-B functional denotation to "survival" rather than an "angiogenic" factor.

We recently found that VEGF-B is a survival factor for multiple types of vascular cells, including vascular endothelial cells (EC), pericytes (PC) and smooth muscle cells (SMC) (Zhang et al., 2009).

VGF-B186 delivery to the heart upregulated the expression of many antiapoptotic genes in cardiomyocytes, and inhibited cardiac myocyte apoptosis, demonstrating a survival effect of VEGF-B 186 on them (Lahteenvuo et al., 2009).

Certain researchers claim VEGF-B to be necessary in adults to ensure proper functioning, however, it is not required in the development of the cardiovascular system and angiogenesis (Roskoski, 2007)

Moreover, Dr Eriksson's group showed that VEGF-B is a critical regulator of energy metabolism by regulating fatty acid uptake ( Hagberg et al., 2010)

It has also been observed that the protein can regulate the FATP (Fatty Acid Transport Proteins) level in vascular walls.

The human VEGF-C gene was first cloned in 1996, while VEGF-D in 1997 (Joukov V et al. 1996; Yamada Y 1997). 
Both factors are synthesised as inactive, multi-molecular pre-pro-proteins comprising end pro-peptides $\mathrm{NH}_{2}$ - and $\mathrm{COOH}$ - and the central homological VEGF domain. The domain contains receptor binding sites (Achen et al., 1998; Joukov et al., 1996; Stacker et al.,1999; Yamada 1997; Kuuk et al., 1996).

The active VEGF-C and VEGF-D forms are formed through inter- and extra-cellular proteolysis of $-\mathrm{C}$ and $-\mathrm{N}$ ends (Achen et al., 1998; Joukov et al., 1996).

The precursor forms of the growth factor interact mainly with the VEGFR-3 receptor while active forms display strong affinity for VEGFR-2 ( Joukov et al., 1997; Stacker et al., 1999).

The functions of VEGF-C and VEGF-D are mainly determined by the receptor they bind with and its location. When either of the factors interacts with the VEGFR-3 receptor located in the lymphatic epithelium, they induce the development and restructuring of lymphatic vessels. In turn, when the active forms of the growth factor bind with the VEGFR-2 receptor in blood vessel epithelium, they influence angiogenesis.

In the course of research conducted on embryos and transgenic animals, it was observed that VEGF-C and the VEGFR-3 receptor play a vital role in the embryonic development of the lymphoid system. Homozygous mice VEGF-C-/- with inactive VEGF-C gene died due to undeveloped lymphoid system. Heterozygous mice VEGF-C ${ }^{-/+}$displayed significant malformation in terms of this system.

In adult humans, high levels of VEGF-C mRNA have been observed in a number of organs, i.e.: the heart, lungs, skeletal muscles, large intestine, small intestine, and thyroid. Relatively small amounts of VEGF-C are known to be produced in the kidneys, pancreas, prostate, and spleen (Roskoski 2007).

VEGF-C overexpression has been observed in a number of tumours in humans, including: breast cancer, colorectal cancer, stomach cancer, thyroid neoplasm, and prostate cancer. High levels of the factor indicate a negative prognosis (Sucha \& Ganesan 2008)

Structural similarities between VEGF-C and VEGF-D as well as their affinity for the VEGFR2 and VEGFR-3 receptors would suggest similar biological qualities of the two. However, VEGF-D does not play as significant a role in the embryonic development of the lymphoid system (Karkkainen et al., 2004). It has been observed that apart from mitogenic activity on endothelial cells, it also stimulates fibroblast division.

High VEGF-D levels are observed in humans mainly in the heart, lungs, skeletal muscles, and small intestine. VEGF-D overexpression is observed in a number of tumours as well, i.e.: breast cancer, colorectal cancer, stomach cancer, thyroid neoplasm, and cervical cancer. Furthermore, the VEGF-D expression level has proved to be an independent prognostic factor in respect to ovarian cancer (Yokoyama et al 2003).

To sum up, VEGF-C and VEGF-D play important roles in lymphangiogenesis and angiogenesis, they also facilitate lymphatic metastasis in lymph nodes.

VEGF-E was identified in the genome of the orf virus (parapoxvirus) which is pathogenic in goats, sheep and sporadically in humans. It is in homological sequence with other proteins of the VEGF family, which may suggest that the gene of the virus VEGF originated from mammal hosts and underwent a genetic drift. It displays proangiogenic activity (Barańska et al., 2005).

PIGF - occurs in homodimer form. Increased concentrations of this factor have been observed in cases of myocardial infarction, retinopathy and neoplastic disease. It is responsible for stimulating the growth of endothelial cells and smooth muscles. Through action synergistic with VEGF-B, it influences the diversification and activation of monocytes (Clauss, 2000; Namiecińska et al., 2005). 
The VEGF family also includes sv-VEGF proteins isolated from snake venom. Due to their homology similar to the VEGF found in mammals, they are often referred to as "VEGF-like" proteins. One such protein has been isolated from the venom of a Bothrops insularis snake (Barańska et al., 2005).

\subsection{VEGF receptors}

VEGF binds to at least three different types of receptors: VEGFR-1 (Flt-1- fms-like tyrosine kinase-1), VEGFR-2 (KDR- kinase domain region in humans and Flk-1- fetal liver kinase-1 in mice), and VEGFR-3 (Flt-4 - fetal liver kinase 4) which belong to a family of receptors containing a tyrosine-kinase domain (Bałan, 2000; Barańska et al, 2005; Breier \& Risau, 1996; Ferrara \& Davis-Smyth, 1997; Namiecińska et al., 2005; Papetti, 2002; Ranieri et al., 2004; Szala \& Radzikowski, 1997; Webb et al., 1998).

VEGFR-1 is found in the epithelium, as well as on the surface of macrophages and monocytes. The receptor is characterised by the highest affinity for the ligand (Kd-10-20 pM). Its expression remains constant in dividing as well as latent cells. It has been observed that the absence of said receptor results in disorders in terms of the structure and morphology of the formed vessels. The same is due to the increase in the number of hemangioblasts accumulating inside the forming vessels and closing them off (Barańska et al., 2005).

In homozygous mice, the receptor's insufficiency leads to vessel hypertrophy and premature death of foetuses in mid pregnancy (Hucz \& Szala, 2006).

VEGFR-1 displays significant affinity for bonding VEGF-A as well as PIGF and VEGF-B (Barańska et al., 2005).

VEGFR-2 is expressed in epithelium cells, retinal stem cells, as well as platelets and hematopoietic cells, mainly during foetal life when the processes of angiogenesis and vasculogenesis are particularly intensive (Bałan, 2000). The amount of mRNA for VEFGR-2 is reduced in the cells of an adult organism. Embryos deprived of the VEGFR-2 receptor do not develop vascularisation and die in early embryogenesis (Shibuya \& Claesson-Welsh 2006) The receptor's affinity for the ligand is lower than in the case of VEGFR-1 (Barańska et al., 2005).

The Flt-1 and KDR/Flk-1 receptors vary in terms of signal transduction mechanisms. Stimulation of the KDR/Flk-1 receptor results in a violent reaction while stimulation of the Flt-1 receptor induces a significantly weaker response. The above suggests that Flt-1 may negatively regulate the process of angiogenesis (Ferrara, 1999), whereas activation of the KDR/Flk-1 receptor increases the proliferational activity of endothelium cells while at the same time inhibiting the process of apoptosis and increasing blood vessel permeability. It has been observed that mouse embryos deprived of the VEGFR-2 receptor will be nonvascularised and will die in the early stage of embryogenesis (Thielemann et al., 2010). The receptor reacts to VEGF-C and VEGF D.

Two distinct receptor tyrosine kinases have been identified for VEGF-A on endothelial cells: VEGFR-1 and VEGFR-2 (Olsson et al., 2006; Shibuya \& Claesson-Welsh, 2006). The affinity of VEGF-A for VEGFR-1 is 10-fold stronger than its affinity for VEGFR-2; nonetheless, most VEGF-A-mediated downstream signaling events associated with angiogenesis require VEGFR-2 activation (Waltenberger et al., 1994, Zachary 2003, Szala 2009). Binding of VEGFR-2 to VEGF induces dimerization and consequent phosphorylation of a subset of intracellular tyrosine residues (Rydén et al., 2003, Chen et al., 2010).

VEGFR-3 has been detected in embryonic epithelial cells. In mature tissue it is present almost exclusively in the lymphatic vessel epithelium cells, which indicates its participation 
in lymphangiogenesis. The receptor does not recognise VEGF-A but does bind with VEGF-C and VEGF-D (Barańska et al., 2005; Namiecińska et al., 2005).

In the 1990s, soluble forms of sVEGFR-1, unanchored in the cell membrane, were discovered. The particulars of the biochemical structure of sVEGFR-1 remain to be determined, but we know that by binding with each isoform of VEGF they serve as negative angiogenesis regulators and inhibit the formation of blood vessels in neoplastic tumours (Thielemann et al., 2010).

\subsection{Regulation of VEGF expression}

VEGF expression is regulated by a number of mechanisms, the most important of which is hypoxia. In conditions of lowered oxygen partial pressure, a sudden increase can be observed in terms of the presence of hypoxia inducible factor - HIF-1a - which activates the VEGF gene promoter - HRE (hypoxia response element), thus intensifying VEGF expression (Breier \& Risau, 1996; Fang et al., 2001; Ferrara, 1999; Namiecińska et al., 2005; Papetti \& Herman, 2002; Rosen, 2002).

The gene's stimulation independent of HIF-1 has also been observed as a result of hypoxia. Due to low oxygen pressure, accumulation of adenosine may occur activating its receptor A2 and causing an increase of cAMP concentration, which in turn leads to elevated levels of mRNA for VEGF. Stimulation of VEGF expression can also be due to the influence of cytokines: EGF, TGF- $\beta$, KGF, PGF 2 , IGF-1, interleukin - IL-1, IL -5, IL-6, IL-9, IL-13, or due to a mutation of certain oncogenes leading to a neoplastic transformation (Barańska et al., 2005; Breier \& Risau, 1996; Gruchlik et al., 2007, Xue et al., 2009). An example of the latter case may be the mutation of gene p-53, which stimulates VEGF expression.

\section{VEGF expression in tumours}

\subsection{VEGF expression profiles in human tumours}

The opinion prevalent in literature is that increased vascular density may result from overexpression of proangiogenic factors, particularly VEGF (Han et al., 2001).

The induction of vessel growth is a process closely regulated by positive and negative angiogenesis regulators. In a mature organism, the two balance each other out, thus preventing vessel carcinogenesis. Any distortion of the balance results in the increased production and action of one or more proangiogenic factors, which leads to the stimulation of angiogenesis (Jośko et al., 2000; Conti, 2002).

It has been suggested by a number of researchers that VEGF is a mitogen of epithelium cells and a strong factor inducing increased vessel permeability. It plays a vital role in the process of neovascularisation, tumour growth and metastasis (Baillie et al., 2001; Barańska et al., 2005; Chhieng et al., 2003; Dvorak, 2002; Grunstein et al., 1999; Hicklin \& Ellis, 2005; Kraft et al., 1999; Litwiniu et al., 2007; Poon et al., 2003; Zheng et al., 2003). Chechlińska also observes that it can activate specific types of integrins on neoplastic cells, which increases invasiveness by allowing tumour cells to anchor to degraded elements of the extracellular matrix (Chechlińska, 2003).

There are a number of publications pertaining to the assessment of immunohistochemical expression of VEGF receptors in cancerous tissues. In the research, anti-VEGF antibodies were used to show receptors in endothelial cells. Takahashi observed elevated expression of the KDR/Flk-1 receptor for VEGF in metastased malignant colorectal cancers, as compared to non-metastased cancers (Takahashi et al., 1995). 
Research has also been conducted on patients suffering from lung cancer (Oshika et al., 1998; Yuan et al., 2001) and women diagnosed with malignant breast cancer (Adams et al., 2000; Lewis et al., 2000; Terman \& Stoletov, 2001). Overexpression of the vascular endothelial growth factor correlated with tumour growth, development of new vessels, and early relapse of the neoplastic disease.

With the use of the real-time PCR exam, the presence of VEGF mRNA can be determined in tumour cells. The highest VEGF mRNA levels have been observed in malignant tumour tissue contiguous with necrotic areas (Ferrara \& Davis-Smyth 1997; Restucci et al., 2002).

Increased VEGF expression, both in terms of mRNA in neoplastic tissues and the protein itself in blood plasma, serum and urine, has been observed in numerous types of neoplastic disease in humans (Ferrara \& Davis-Smyth, 1997; Łojko \& Komarnicki, 2004). Elevated VEGF concentrations in blood plasma have been noted in patients diagnosed with colorectal cancer, lung cancer, and breast cancer in women. It typically constituted a bad prognosis and indicated the presence of distant metastases (Chhieng et al., 2003; Ferrara \& Davissmyth, 1997; Han et al., 2001; Litwiniuk et al., 2007; Zheng et al., 2003; Kopczyńska et al., 2008; Wójcik et al., 2010).

Overproduction of VEGF has also been observed in neoplastic cells of aberrant ovaries. The growth factor was identified in the peritoneal effusions from female patients diagnosed with malignant neoplastic growths, which suggests its secretion by cancerous cells (Gawrychowski et al., 1997).

Elevated VEGF levels have also been noted in hematologic hyperplasia. In myeloid leukaemia, elevated VEGF levels correlated with shorter survivability and lower probability of full remission (Łojko \& Komarnicki, 2004).

Kozaczka et al. observed significantly higher levels of serum VEGF in patients diagnosed with surgical colorectal andenocarcinoma, when compared to the control population. They concluded that the level of vascular endothelial growth factor was the only statistically significant parameter of prognostic value (Kozaczka et al., 2004).

Elevated levels of VEGF expression, related to bad prognoses and high likelihood of metastasis, have been observed in various types of malignant tumours in humans (Epstein et al., 2001; Poon et al., 2003; Yu et al., 2002; Yuan et al., 2001). A correlation has also been observed between the VEGF value and the level of malignancy in tumours of: lungs, breasts, thyroids, stomachs, intestines, kidneys, bladders, ovaries, oral cavities, as well as angiosarcomas, and nervous system neoplasms (Chao et al., 2001; Han et al., 2001; Nicosia, 1998; Yuan et al., 2001).

Research has also been conducted into the expression of serum VEGF in patients suffering from melanoma. Elevated VEGF levels in the serum were observed in patients with advanced neoplastic process. It indicated significantly shorter periods of remission and, as suggested by the author, was of prognostic value (Ascierto et al., 2004;Yu et al., 2002).

Available literature devotes significant attention to the correlation between the vessel density in cancerous tissue and the expression of VEGF in blood serum or tumour cells (Adams et al., 2000; Ferrara, 1999; Kondo et al., 2000; Loggini et al., 2003; Takahashi et al., 1995; Zheng et al., 2003).

Said correlation has been observed in squamous skin carcinomas in humans. Some researchers suggest that the correlation between the number of vessels and the increased expression of vascular endothelial growth factor mRNA can prove valuable in determining the malignancy level of such cancers (Loggini et al., 2003). The development of vessels accompanied by increased concentrations of VEGF mRNA as well as of the protein itself in 
tumour tissues has also been observed in cases of colorectal adenoma (Kondo et al., 2000; Takahashi et al., 1995) and breast cancer (Adams et al., 2000) in humans, where it indicated unfavourable prognoses.

It is assumed that the negative correlation between the number of vessels in a tumour and the level of VEGF as the main proangiogenic factor may be due to the process known as vascular mimicry. It is a process in which angioid channels are formed outside the epithelium. Literature indicates that said phenomenon can be observed in the case of malignant melanomas (Folberg et al., 2000; McDonald et al., 2000).

\subsection{VEGF expression profiles in dog tumours}

Comparative studies have been performed in respect to human and animal VEGF structure. It was demonstrated that all main isoforms of the vascular endothelial growth factor are present in dogs, and that amino acid sequences in the areas responsible for binding with receptors are identical in humans and animals. Furthermore, it has been observed that canine VEGF activates human endothelial cells to the same extent as the human growth factor. In dogs, it occurs in tumours at similar volumetric ratios to those observed in human malignant tumours (Mohammed et al., 2002; Scheidegger et al., 1999).

The immunohistochemiacal reaction of VEGF expression has also been studied in squamous carcinomas and skin basaliomas in dogs (Maiolino et al., 2004). The presence of the growth factor was observed in all squamous cancers, particularly those located in the vicinity of toes, while it was not detected in the studied basaliomas. Similar results were obtained in the course of research on human squamous carcinoma (Loggini et al., 2003; Oshika et al., 1998). It is believed that the presence of VEGF in squamous cancers may serve as a viable, additional criterion in determining the malignancy and growth capacity of tumours in both dogs and humans.

The growth factor has been determined in the blood serum of dogs diagnosed with angiosarcoma. It was observed that elevated VEGF levels in dog blood serum occurred in dogs suffering from cancer. It did not, however, correlate with the advancement stage of the disease or the size of the tumour (Clifford et al., 2001). Similar results were obtained by Wergin and Kaser-Hotz. They observed that in healthy dogs the level of VEGF was indiscernible, while in dogs suffering from the neoplastic disease it was high and the obtained results were statistically significant (Wergin \& Kaser-Hotz, 2004; Wergin et al., 2004).

Elevated VEGF levels have also been observed in the urine of dogs diagnosed with malignant bladder cancer (Mohammed et al., 2002).

Our own research indicated statistically significant VEGF values in the blood serum of dogs suffering from malignant skin neoplasms. An analysis of own research results as well as data available in literature suggests that the blood serum levels of VEGF may indeed constitute a valuable prognostic criterion and be a viable indicator in early diagnoses of carcinomas. Overexpression of the vascular endothelial growth factor observed in malignant tumours, confronted with the clinical picture of the neoplasia, may influence the choice of treatment and facilitate the prognosis of its therapeutic effect (Sobczyńska-Rak, 2009).

A study on vascular density in mammary carcinomas in dogs yielded similar results to those obtained in humans. The correlation between the number of capillaries and elevated VEGF levels was again observed (Restucci et al., 2002).

In the course of own research, a correlation was observed between vessel density and serum VEGF levels in benign and malignant skin cancers in dogs. A negative correlation was indicated in the case of oral cancer, while no correlation was observed in the case of 
mammary cancer. The results indicate that both angiogenesis and the growth factor have significant prognostic value in terms of determining the malignancy level of skin cancer. The potential value of the same in respect to oral cancer and mammary cancer remains to be determined (Sobczyńska-Rak, 2009).

Research by other authors conducted on dogs suffering from mammary cancer indicates that VEGF stimulates the proliferation and migration of endothelial cells and therefore influences angiogenesis. However, for a functional vessel to be formed other growth factors are required (Restucci et al. 2002; Troy et al., 2006).

To sum up, overexpression of VEGF in blood serum, bodily fluids, or neoplastic tissue often correlates with angiogenesis, growth and metastasis in both human and animal cancers. The observed close relations suggest the notion of treating neoplastic disease through inhibiting the formation of blood vessels in cancerous tissues. A particularly promising treatment approach may prove to be the use of VEGF antibodies (Gruchlik et al., 2007; StępieńWyrobiec et al., 2007, Hashizume et al., 2010) and clinical research into the matter is currently being conducted worldwide. In recent years, intensive research has been underway into anti-neoplasmic treatments with the use of cytostatic agents in combination with agents inhibiting VEGF expression or blocking its receptors. The results so far show considerable promise and may constitute a significant breakthhrough in the fight against neoplastic disease ( Volk et al., 2011)

\section{References}

Achen M.G., Jeltsch M., Kukk E., Makinen T., Vitali A., Wilks A.F., Alitalo K., Stacker S.A. 1998. Vascular endothelial growth factor D (VEGF-D) is a ligand for the tyrosine kinases VEGF receptor 2 (Flk1) and VEGF receptor 3 (Flt4). Proc. Natl. Acad. Sci. 95, 548-53

Adams J., Carder P. J., Downey S., Forbes M. A., MacLennan K., Allgar V., Kaufman S., Hallam S., Bicknell R., Walker J. J., Cairnduff F., Selby P. J., Perren T. J., Lansdown M., Banks R. E. 2000. Vascular Endothelial Growth Factor (VEGF) in breast cancer: comparison of plasma, serum, and tissue VEGF and microvessel density and effects of Tamoxifen. Cancer Res. 60, 2898-2905.

Ascierto P. A., Leonardi E., Ottaiano A., Napolitano M., Scala S., Castello G. 2004. Prognostic volue of serum VEGF in melanoma patients: a pilot study. Anticancer Res. 24, 42554258 .

Baillie R., Carlile J., Pendleton N., Schor A. M. 2001. Prognostic value of vascularity and vascular endothelial growth factor expression in non-small cell lung cancer. J. Clin. Pathol. 54, 116-120.

Bałan B. J. 2000. Angiogenesis - problem of XXI century. Nowa Medycyna 4, 8-14.

Bałan B. J., Słotwiński R. 2008. VEGF and tumor angiogenesis. Centr. Eur. J Immunol. 33, 232-236.

Barańska P., Jerczyńska H., Pawłowska Z. 2005. Vascular endothelial growth factorstructure and functions. Postępy Biochem. 51, 13-21.

Biedka M., Makarewicz R., Lebioda A., Kardymowicz H., Goralewska A. 2010. Vascular endothelial growth factor $\mathrm{C}$ as a predictive factor In cervical cancer? Współczesna Onkologia, 14, 87-92.

Breier G., Risau W. 1996. The role of vascular endothelial growth factor in blood vessel formation. Cell Biol. 6, 454-456. 
Chao C., Al-Saleem T., Brooks J. J., Rogatko A., Kraybill W. G., Eisenberg B. 2001. Vascular Endothelial Growth Factor and soft tissue sarcomas: tumor expression correlates with grade. Ann. Surg. Oncol. 8, 260-267.

Chechlińska M. 2003. The role of cytokines in carcinogenesis. Nowotwory 6, 648-659.

Chen T. T., Luque A., Lee S., Anderson S. M., Segura T., Iruela-Arispe M. L. 2010. Anchorage of VEGF to the extracellular matrix conveys differential signaling responses to endothelial cells. J. Cell Biol. 188, 595-609

Chhieng D. C., Tabbara S. O., Marley E. F., Talley L. I., Frost A. R. 2003. Microvassel density and Vascular Endothelil Growth Factor expression in infiltrating lobular mammary carcinoma. Breast J. 9, 200-207.

Clauss M. 2000. Molecular biology of the VEGF and VEGF receptor family. Semin. Tromb. Hemost. 26, 561-569.

Clifford C. A., Hughes D., Beal M. W., Mackin A. J., Henry C. J., Shofer F. S., Sorenmo K. U. 2001. Plasma vascular endothelial growth factor concentrations in healthy dogs and dogs with hemangiosarcoma. J. Vet. Intern. Med. 15, 131-135.

Connolly, D. T., Olander, J. V., Heuvelman, D., Nelson, R., Monsell, R., Siegel, N., Haymore, B. L., Leimgruber, R., and Feder, J. 1989. Human vascular permeability factor. Isolation from U937 cells. J. Biol. Chem. 264, 20017-24.

Conti C. J. 2002. Vascular endothelial growth factor: regulation in the mouse skin carcinogenesis model and use in antiangiogenesis cancer therapy. Oncologist. 7, 411.

Dvorak H. F., Orenstein, N. S., Carvalho A. C., Churchill, W. H., Dvorak A. M., Galli S. J., Feder J., Bitzer A. M., Rypysc J., Giovinco P. 1979. Induction of a fibrin-gel investment: an early event in line 10 hepatocarcinoma growth mediated by tumorsecreted products. J. Immunol. 122, 166-174.

Dvorak H. F. 2002. Vascular permeability factor/ Vascular Endothelial Growth Factor: a critical cytokine in tumor angiogenesis and a potential target for diagnosis and therapy. J. Clin. Oncol. 20, 4368-4380.

Epstein S. E., Kornowski R., Fuchs S., Dworak H. F. 2001. Angiogenesis therapy. Circulation $104,115$.

Fang J., Yan L., Shing Y., Moses M. A. 2001. HIF-1 $\alpha$-mediated up-regulation of Vascular Endothelial Growth Factor, independent of Basic Fibroblast Growth Factor, is important in the switch to the angiogenic phenotype during early tumorigenesis. Cancer Res. 61, 5731-5735.

Ferrara N. 1999. Molecular and biological properties of Vascular Endothelial Growth Factor. J. Mol. Med. 77, 527-543.

Ferrara N., Davis-Smyth T. 1997. The biology of vascular endothelial growth factor. Endocr. Rev. 18, 4-25.

Ferrara N., Henzel W. J. 1989. Pituitary follicular cells secrete a novel heparin-binding growth factor specific for vascular endothelial cells. Biochem. Biophys. Res. Commun. 161, 851-858.

Folberg R., Hendrix M. J. C., Maniotis A. J. 2000. Vasculogenic mimicry and tumors angiogenesis. Am. J. Pathol. 156, 361-381.

Gawrychowski K., Barcz E., Kamiński P. 1997 Angiogenesis in the ovarian cancer. Nowotwory 47, 775-784. 
Gospodarowicz D., Abraham J. A., Schilling J. 1989. Isolation and characterization of a vascular endothelial cell mitogen produced by pituitary-derived folliculo stellate cells. Proc. Natl. Acad. Sci. USA 86, 7311-7315.

Grimmond S., Lagercrantz J., Drinkwater C., Silins G., Townson S., Pollock P., Gotley D., Carson E., Rakar S., Nordenskjold M., Ward L., Hayward N., Weber G. 1996. Cloning and characterization of a novel human gene related to vascular endothelial growth factor. Genome Res. 6, 124-13.

Gruchlik A., Chodurek E., Domal-Kwiatkowska D., Dzierżewicz Z. 2007. VEGF-A-target of antiangiogenic cancer therapy. Postępy Biol. Kom. 3, 557-580.

Grunstein J., Roberts W. G., Mathieu- Castello O., Hanahan D., Johnson R. S. 1999. Tumorderived expression of vascular endothelial growth factor is a critical factor in tumor expansion and vascular function. Cancer Res. 59, 1592-1598.

Han H., Silverman J. F., Santucci T. S., Macherey R. S., dAmato T. A., Tung M. Y., Weyant R. J., Landreneau R. J. 2001. Vascular Endothelial Growth Factor expression in stage I non-small cell lung cancer correlates with neoangiogenesis and a poor prognosis. Ann. Surg. Oncol. 8, 72-79.

Hargberg C. E., Falkevall A., Wang X., Larsson E., Huusko J., Nilsson I., van Meeteren L. A., Samen E., Lu L., Vanwildemeersch M., Klar J., Genove G., Pietras K., Stone-Elander S., Claesson-Welsh L., Ylä-Herttuala S., Lindahl P., Eriksson U. 2010. Vascular endothelial growth factor B controls endothelial fatty acid uptake. Nature 464, 917921.

Hashizume H., Falcón B. L., Kuroda T., Baluk P., Coxon A., Yu D., Bready J.V., Oliner J.D., McDonald D.M. 2010. Complementary actions of inhibitors of angiopoietin-2 and VEGF on tumor angiogenesis and growth Cancer Res. 70, 2213-2223.

Hicklin D. J., Ellis L. M. 2005. Role of Vascular Endothelial Growth factor pathway in tumor growth and angiogenesis. J. Clin. Oncol. 23, 1011-1027.

Hoeben A., Landuyt B., Highley M. S., Wildiers H., Van Osterom A. T., De Bruijn E. A. 2004. Vascular Endothelial Growth Factor and Angiogenesis. Pharmacol. Rev. 56, 549-580

Houck K. A., Leung D. W., Rowland A. M., Winer J., Ferrara N. 1992. Dual regulation of vascular endothelial growth factor bioavailability by genetic and proteolytic mechanisms. J. Biol. Chem. 267, 26031-26037.

Hucz J., Szala S. 2006. VEGFR-2 receptor - target for anticancer therapy. Współczesna Onkologia 10, 506-514.

Jośko J., Gwóźdź B., Jędrzejowska-Szypułka H., Henryk S. 2000. Vascular endothelial growth factor (VEGF) and its effect on angiogenesis. Med. Sci. Monit. 6, 1047-1052.

Joukov V., Pajusola K., Kaipainen A., Chilov D., Lahtinen I., Kukk E., Saksela O., Kalkkinen N., Alitalo K. 1996. A novel vascular endothelial growth factor, VEGF-C, is a ligand for the Flt4 (VEGFR-3) and KDR (VEGFR-2) receptor tyrosine kinases. EMBO J. 15, 290-298.

Joukov V., Pajusola K., Kaipainen A., Chilov D., Lahtinen I., Kukk E., Saksela O., Kalkkinen N., Alitalo K. 1996. A novel vascular endothelial growth factor, VEGF-C, is a ligand for the Flt4 (VEGFR-3) and KDR (VEGFR-2) receptor tyrosine kinases. EMBO J. 15, 290-298.

Karkkainen M.J., Haiko P., Sainio K., Partanen J., Taipale J., Petrova T.V., Jeltsch M., Jackson D.G., Talikka M., Rauvala H., Betsholtz C., Alitalo K. 2004. Vascular endothelial growth factor $\mathrm{C}$ is required for sprouting of the first lymphatic vessels from embryonic veins. Nat. Immunol. 5, 74-80. 
Kondo Y., Arii Sh., Mori A., Furutani M., Chiba T., Imamura M. 2000. Enhancement of angiogenesis, tumor growth, and metastasis by transfection of Vascular Endothelial Growth Factor into LoVo human colon cancer cell line. Cancer Res. 6, 622-630.

Kopczyńska E., Dancewicz M., Kowalewski J., Tyrakowski T. 2008. The comparison of prognostic value of VEGF and MMP-9 in non-small cell lung cancer during threeyear observation after anti-tumour treatment Współcz. Onkol. 12, 370-373.

Kozaczka A., Najda J., Waszczyk D. 2004: Angiogenesis controlling mechanisms and their clinical application in advanced cases of colorectal cancer. Współcz. Onkol. 8, 373378.

Kraft A., Weindel K., Ochs A., Marth C., Zmija J., Schumacher P., Unger C., Marme D., Gastl G. 1999. Vascular endothelial growth factor in the sera and effusion of patients with malignant and nonmalignant disease. Cancer 85, 178-187.

Kukk E, Lymboussaki A, Taira S, Jeltsch M, Joukov V, Alitalo K. 1996. VEGF-C receptor binding and pattern of expression with VEGFR-3 suggests a role in lymphatic vascular development. Development 122, 3829-3837

Lahteenvuo J. E., Lahteenvuo M. T., Kivela A., Rosenlew C., Falkevall A, Klar J, Heikura T., Rissanen T. T., Vähäkangas E., Korpisalo P., Enholm B., Carmeliet P., Alitalo K., Eriksson U., Ylä-Herttuala S. 2009. Vascular endothelial growth factor-B induces myocardium-specific angiogenesis and arteriogenesis via vascular endothelial growth factor receptor-1- and neuropilin receptor-1-dependent mechanisms. Circulation 119, 845-856.

Lewis J. S., Landers R. J., Underwood J. C., Harris A. L., Lewis C. E. 2000. Expession of vascular endothelial growth factor by macrophages is upregulated in poorly vascularized areas of breast carcinomas. J. Pathol. 192, 150-158.

Li X., Aase K., Li H., Von Euler G., Eriksson U. 2001. Isoform-specific expression of VEGF-B in normal tissues and tumors. Growth Factors 19, 49-59

Li X., Lee Ch., Tang Z., Zhang F., Arjunan P., Li Y., Hou X., Kumar A., Dong L. 2009 VEGF-B a survival or angiogenic factor? Cell Adh. Migr. 3, 322-327

Li X. 2010.VEGF-B: a thing of beauty. Cell Res. 20, 741-744.

Litwiniuk M., Łojko A., Thielemann A., Kopczyński Z. 2007. Vascular endothelial growth factor (VEGF) and selected clinicopathological parameters in breast carcinoma. Współcz Onkol. 11, 300-304.

Loggini B., Boldrini L., Gisfredi S., Ursino S., Camacci T., De Jeso K., Cervadoro G., Pingitore R., Barachini P., Leocata P., Fontanini G. 2003. C34 microvessel density and VEGF expression in basal and squqmous cell carcinoma. Pathol. Res. Pract. 199, 705-712.

Łojko A., Komarnicki M. 2004. Vascular endothelial growth factor In tumor angiogenesis. Współ. Onkol. 8, 1-4.

Łukasik A., Fila A., Michalski B., Pordzik P., Poręba R., Wilczok T., Mazurek U. 2003. Estimation of risk progression in low grade squamous intraepithelial lesions in aspect of occurrence of alternative splice mRNA VEGF forms - VEGF $121, V V_{145}$, VEGF $_{165}, V \mathrm{VGF}_{183}, \mathrm{VEGF}_{189}, \mathrm{VEGF}_{206}$. Współcz. Onkol. 7, 286-293.

Maiolino P, De Vico G, Restucci B. 2000. Expression of vascular endothelial growth factor in basal cell tumours and in squamous cell carcinomas of canine skin. J Comp. Pathol. 123, 141-145.

McDonald D. M., Munn L., Jain R. K. 2000. Vasculogenic mimicry: how convinicing, how novel and how sifnificant? Am. J. Pathol. 156, 383-388. 
McMahon G. 2000. VEGF receptor signaling in tumor angiogenesis. Oncologist. 5, 3-10.

Mohammed S. I, Bennett P. F, Craig B. A, Glickman N. W., Mutsaers A. J., Snyder P. W., Widmer W. R., DeGortari A. E., Bonney P.L., Knapp D. W. 2002. Effects of the cyclooxygenase inhibitor, piroxicam, on tumor response, apoptosis, and angiogenesis in a canine model of human invasive urinary bladder cancer. Cancer Res. 62, 356-358.

Namiecińska M., Marciniak K., Nowak J. Z. 2005. VEGF as an angiogenic, neurotropic, and neuroprotective factor. Post. Hig. Med. Dośw. 59, 573-583.

Nicosia R. F. 1998. What is the role of Vascular Endothelial Growth Factor-related molecules in tumor angiogenesis? Am. J. Pathol. 153, 11-16.

Olsson, A.K., A. Dimberg, J. Kreuger, and L. Claesson-Welsh. 2006. VEGF receptor signalling - in control of vascular function. Nat. Rev. Mol. Cell Biol. 7,359-371.

Olofsson B., Pajusola K., von Euler G., Chilov D., Alitalo K., Eriksson U. 1996.Genomic organization of the mouse and human genes for vascular endothelial growth factor B (VEGF-B) and characterization of a second splice isoform. J. Biol. Chem. 271, 19310-10317.

Olofsson B., Korpelainen E., Pepper M.S., Mandriota S.J., Aase K.,Kumar V., Gunji Y., Jeltsch M.M., Shibuya M., Alitalo K., Eriksson U. 1998. Vascular endothelial growth factor B (VEGF-B) binds to VEGF receptor-1and regulates plasminogen activator activity in endothelial cells. Proc. Natl. Acad. Sci. 95, 11709-11714.

Oshika Y., Nakamura M., Tokunaga T., Ozeki. Y, Fukushima Y., Hatanaka H., Abe Y., Yamazaki H., Kijima H., Tamaoki N., Ueyama Y. 1998. Expression of cell-associated isoform of vascular endothelial growth factor 189 and its prognostic relevance in non-small cell lung cancer. Int. J. Oncol. 12, 541-544.

Papetti M., Herman I. M. 2002. Mechanisms of normal and tumor-derived angiogenesis. Am. J. Physiol. Cell Physiol. 282, 947-970.

Plouët J., Schilling J., Gospodarowicz D. 1989. Isolation and characterization of a newly identified endothelial cell mitogen produced by AtT-20 cells. EMBO J. 8, 3801-3806

Poon R. T., Lau C. P., Cheung S. T., Yu W. C., Fan S.T. 2003. Quantitative correlation of serum levels and tumor expression of vascular endothelial growth factor in patients with hepatocellular carcinoma. Cancer Res. 63, 3121-3126.

Ranieri G., Coviello M., Chiriatti A., Stea B., Montemurro S., Quaranta M., Dittadi R., Paradiso A. 2004. Vascular endothelial growth factor assessment in different blood fractions of gastrointestinal cancer patients and healthy controls. Oncol. Rep. 11, 435-439.

Restucci B., Papparella S., Maiolino P., De Vico G. 2002. Expression of vascular endothelial growth factor in canine mammary tumors. Vet. Pathol. 39, 488-493.

Rofstad E. K, Halsor E. F. 2000. Vascular Endothelial Growth Factor, Interleukin 8, Plateletderived Endothelial Cell Growth Factor, and Basic Fibroblast Growth Factor Promote Angiogenesis and Metastasis in Human Melanoma Xenografts. Cancer Res. 60, 4932-4938.

Rosen L. S. 2002. Clinical experience with angiogenesis signaling inhibitors: focus on vascular endothelial growth factor (VEGF) blockers. Cancer Control. 9, 36-44.

Roskoski R. Jr. 2007. Vascular endothelial growth factor (VEGF) signaling in tumor progression. Oncology/Hematology 62, 179-213. 
Rydén L., Linderholm B., Nielsen N. H., Emdin S., Jönsson P. E., Landberg G. 2003. Tumor specific VEGF-A and VEGFR2/KDR protein are co-expressed in breast cancer. Breast Cancer Res Treat. 82, 147-54.

Scheidegger P., Weiglhofer W., Suarez S., Kaser-Hotz B., Steiner R., Ballmer-Hofer K., Jaussi R. 1999. Vascular endothelial growth factor (VEGF) and its receptors in tumorbearing dogs. Biol. Chem. 380, 1449-1454.

Senger D. R., Galli S. J., Dvorak A. M., Perruzzi C. A., Harvey V. S., Dvorak H. F. 1983. Tumor cells secrete a vascular permeability factor that promotes accumulation of ascites fluid. Science 219, 983-985.

Senger D. R., Perruzzi C. A., Feder J., Dvorak H. F. 1986. A highly conserved vascular permeability factor secreted by a variety of human and rodent tumor cell lines. Cancer Res. 46, 5629-32.

Shibuya, M., Claesson-Welsh L. 2006. Signal transduction by VEGF receptorsin regulation of angiogenesis and lymphangiogenesis. Exp. Cell Res. 312, 549-560.

Sobczyńska-Rak A. 2009. Correlation between plasma VEGF and angiogenesis of skin and subcutaneous tissue cancer in dogs. Bull Vet Inst Pulawy 53, 503-506.

Stacker S.A., Stenvers K., Caesar C., Vitali A., Domagala T., Nice E., Roufail S., Simpson R.J., Moritz R., Karpanen T., Alitalo K., Achen M.G. 1999. Biosynthesis of vascular endothelial growth factor-D involves proteolytic processing which generates noncovalent homodimers. J. Biol. Chem. 274, 32127-32136.

Stępień-Wyrobiec O., Wyrobiec G., Rokicki W., Harabin-Słowińska M. 2007. Vascular endothelial growth factor (VEGF) - a regulator of angiogenesis. Ann. Acad. Med. Siles., 61, 152-160.

Sundar S. S., Ganesan T. S. 2007. Role of lymphangiogenesis in cancer. J Clin Oncol. 25, 42984307

Swidzińska E., Naumniuk E., Chyczewska E. 2006 Angiogenesis and neoangiogenesis - the role in lung cancer and other tumors. Pulmunol. Alergol. Pol. 74, 414-420.

Szala S. 2009. Angiogenesis and immune supression: yin and yang of tumor progression? Postepy Hig. Med. Dośw. 63, 598-612.

Szala S., Radzikowski Cz. 1997. Molecular basis of neoplastic angiogenesis. Nowotwory 47, 1-19.

Takahashi Y., Kitadi Y., Bucana C. D., Cleary K. R., Ellis L. M. 1995. Expresion of vascular endothelial growth facto rand its receptor, KDR, correlates with vascularity, metastasis, and proliferation of human colon cancer. Cancer Res. 55, 3964-3968.

Terman B. I., Stoletov K. V. 2001. VEGF and tumor angiogenesis. Jpn. J. Clin. Oncol. 18, 5966.

Thielemann A., Kopczyński Z., Baszczuk A., Ćwiklińska K., Grodecka-Gazdecka S. 2010. Assessment of sVEGF-1 concentration In patients with breast cancer. Współczesna Onkologia 14, 189-195.

Troy G. C., Huckle W. R., Rossmeisl J. H., Panciera D., Lanz O., Robertson J. L., Ward D. L. 2006. Endostatin and vascular endothelial growth factor concentrations in healthy dogs, dogs with selected neoplasia, and dogs with nonneoplastic diseases. J. Vet. Intern. Med. 20, 144-150.

Volk L. D., Flister M. J., Bivens Ch. M., Stutzman A., Desai N., Trieu V., Ran S. 2008. Nabpaclitaxel efficacy in the orthotopic model of human breast cancer is significantly enhanced by concurrent anti-Vascular Endothelial Growth Factor A therapy. Neoplasia 10, 613-623. 
Volk L. D., Flister M. J., Chihade D., Desai N., Trieu V., Ran S. 2001. Synergy of nabpaclitaxel and bevacizumab in eradicating large orthotopic breast tumors and preexisting metastases. Neoplasia 13, 327-338.

Waltenberger J., Claesson-Welsh L., Siegbahn A., Shibuya M., Heldin C. H. 1994. Different signal transduction properties of KDR and Flt1, two receptors for vascular endothelial growth factor. J. Biol. Chem. 269, 26988-26995.

Webb N. J. A., Myers C. R., Watson C. J., Bottomley M. J., Brenchley P. E. C. 1998. Activated human neurophilis express vascular endothelial growth factor (VEGF). Cytokine 10, 254-257.

Wergin M. C., Kaser - Hotz B. 2004. Plasma vascular endothelial growth factor (VEGF) measured in seventy dogs with spontaneously occurring tumours. In. Vivo. 18, 1519.

Wergin M. C., Ballmer-Hofer K., Roos M., Achermann R. E., Inteeworn N., Akens M. K., Blattmann H., Kaser-Hotz B. 2004. Preliminary study of plasma vascular endothelial growth factor (VEGF) during low- and high-dose radiation therapy of dogs with spontaneous tumors. Vet. Radiol. Ultrasound. 45, 247-54.

Wojtukiewicz M. Z., Sierko E. 2009. The approach to antiangiogenic therapy in cancer patients. Onkol. Prak. Klin. 5, supl. 1-14.

Wójcik E., Sas-Korczyńska B., Stasik Z., Tarapacz J., Rychlik U., Kulpa J. K. 2010. MMP-9, TIMP-1 and VEGF in small cell lung cancer patients. J. Lab. Diagnost. 46, 299-305.

Xue Y., Chen F., Zhang D., Lim S., Cao Y. 2009. Tumor-derived VEGF modulates hematopoiesis. J. Angiogenes Res. 23, 1-9.

Yamada Y., Nezu J., Shimane M., Hirata Y. 1997. Molecular cloning of a novel vascular endothelial growth factor, VEGF-D. Genomics. 42, 483-8.

Yokoyama Y., Charnock-Jones D.S., Licence D., Yanaihara A., Hastings J.M., Holland C.M., Emoto M., Umemoto M., Sakamoto T., Sato S., Mizunuma H., Smith S.K. 2003. Vascular endothelial growth factor-D is an independent prognostic factor in epithelial ovarian carcinoma. Br. J. Cancer 88, 237-244

Yu J. L., Rak J. W., Klement G., Kebel R. S. 2002. Vascular endothelial growth factor isoform expression as a determinant of blood vessel patterning in human melanoma xenografts. Cancer Res. 62, 1838-1846.

Yuan B. A., Yu C. J., Kuo S. H., Chen W. J., Lin F. Y., Luh K. T., Yang P. C., Lee Y. C. 2001. Vascular endothelial growth factor 189 mRNA isoform expression specifically correlates with tumor angiogenesis, patient survival, and postpertive relapse in non-small-cell lung cancer. J. Clin. Oncol. 19, 432-441.

Zachary I. 2003. Biochem. Soc. Trans. 31, 1171-1177

Zheng S., Han M. Y., Xiao Z. X., Peng J. P., Dong Q. 2003. Clinical significance of vascular endothelial growth factor expression and neovascularization in collateral carcinoma. Gastroenterol. 9, 1227-1230.

Zhang F., Tang Z., Hou X., Lennartsson J., Li Y., Koch A. W., Scotney P., Lee C., Arjunan P., Dong L., Kumar A., Rissanen T. T., Wang B., Zhu C., Fariss R., Dong L., Tansey G., Raber J., Fong G., Ding H., Greenberg D., Becker K.G., Nash A., Cao Y., Watts R. J., Li X. 2009.VEGF-B is dispensable for blood vessel growth but critical for their survival, and VEGF-B targeting inhibits pathological angiogenesis. Proc. Natl. Acad. Sci. 106, 6152-6157. 


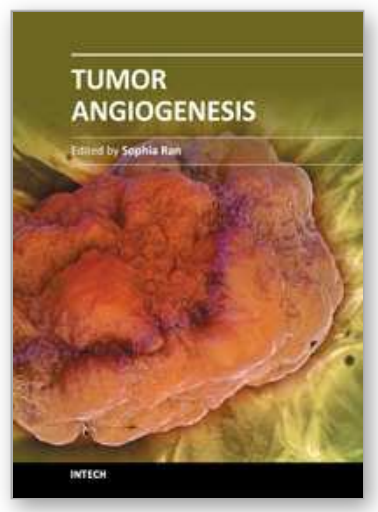

\author{
Tumor Angiogenesis \\ Edited by Dr. Sophia Ran
}

ISBN 978-953-51-0009-6

Hard cover, 296 pages

Publisher InTech

Published online 17, February, 2012

Published in print edition February, 2012

Tumor angiogenesis is the main process responsible for the formation of new blood vessels that promote tumor growth and metastasis. This process is driven by potent pro-angiogenic factors that are predominant in the tumor environment and are produced by both malignant cells and the host cells recruited to the tumor site. Tumor environment is characterized by the imbalance between pro-angiogenic and anti-angiogenic factors, which drives the construction of numerous but structurally defective vessels. These poorly perfused and abnormal vessels significantly contribute to the tumor pathology not only by supporting the expansion of the tumor mass but also by promoting chronic inflammation, enhancing thrombosis, impeding drug delivery, and disseminating tumor cells. These problems associated with tumor vasculature continue to attract great attention of scientists and clinicians interested in advancing the understanding of tumor biology and development of new drugs. This book complies a series of reviews that cover a broad spectrum of current topics related to the pathology of tumor blood vessels including mechanisms inducing new vessels, identification of new targets for inhibition of tumor angiogenesis, and potential clinical use of known and novel anti-angiogenic therapies. The book provides an update on tumor angiogenesis that could be useful for oncologists, cancer researchers and biologists with interests in vascular and endothelial cell behavior in the context of cancer.

\title{
How to reference
}

In order to correctly reference this scholarly work, feel free to copy and paste the following:

Aleksandra Sobczyńska-Rak (2012). The Role of VEGF in the Process of Neovasculogenesis, Tumor Angiogenesis, Dr. Sophia Ran (Ed.), ISBN: 978-953-51-0009-6, InTech, Available from: http://www.intechopen.com/books/tumor-angiogenesis/the-role-of-vegf-in-the-process-of-neovasculogenesis-

\section{INTECH}

open science | open minds

\author{
InTech Europe \\ University Campus STeP Ri \\ Slavka Krautzeka 83/A \\ 51000 Rijeka, Croatia \\ Phone: +385 (51) 770447 \\ Fax: +385 (51) 686166 \\ www.intechopen.com
}

\author{
InTech China \\ Unit 405, Office Block, Hotel Equatorial Shanghai \\ No.65, Yan An Road (West), Shanghai, 200040, China \\ 中国上海市延安西路65号上海国际贵都大饭店办公楼 405 单元 \\ Phone: +86-21-62489820 \\ Fax: +86-21-62489821
}


(C) 2012 The Author(s). Licensee IntechOpen. This is an open access article distributed under the terms of the Creative Commons Attribution 3.0 License, which permits unrestricted use, distribution, and reproduction in any medium, provided the original work is properly cited. 